\title{
Boundary Spanners in Global Partnerships
}

A Case Study of an Indian Vendor's Collaboration With Western Clients

Søderberg, Anne-Marie; Romani, Laurence

Document Version

Accepted author manuscript

Published in:

Group \& Organization Management

DOI:

10.1177/1059601117696618

Publication date:

2017

License

Unspecified

Citation for published version (APA):

Søderberg, A-M., \& Romani, L. (2017). Boundary Spanners in Global Partnerships: A Case Study of an Indian Vendor's Collaboration With Western Clients. Group \& Organization Management, 42(2), 237-278.

https://doi.org/10.1177/1059601117696618

Link to publication in CBS Research Portal

\section{General rights}

Copyright and moral rights for the publications made accessible in the public portal are retained by the authors and/or other copyright owners and it is a condition of accessing publications that users recognise and abide by the legal requirements associated with these rights.

Take down policy

If you believe that this document breaches copyright please contact us (research.lib@cbs.dk) providing details, and we will remove access to the work immediately and investigate your claim. 


\section{Boundary Spanners in Global Partnerships: A Case Study of an Indian Vendor's Collaboration With Western Clients}

\section{Anne-Marie Soderberg and Laurence Romani}

Journal article (Accepted version)

CITE: Boundary Spanners in Global Partnerships : A Case Study of an Indian Vendor's Collaboration With Western Clients. / Søderberg, Anne-Marie; Romani, Laurence. In: Group \& Organization Management, Vol. 42, №. 2, 2017, p. 237-278.

Copyright @ The Authors 2017. Reprinted by permission of SAGE Publications.

\section{DOI: 10.1177/1059601117696618}

Uploaded to Research@CBS: November २०1८ 


\title{
Anne-Marie Søderberg and Laurence Romani
}

\author{
Copenhagen Business School and Stockholm School of Economics
}

\section{BOUNDARY-SPANNERS IN GLOBAL PARTNERSHIPS:}

\section{A Case Study of an Indian Vendor's Collaboration with \\ Western Clients}

\begin{abstract}
Western companies' outsourcing of projects to emergent markets is increasingly being replaced by strategic partnerships that require close collaboration between clients and vendors. This study focuses on interorganizational boundary-spanning activities in the context of global information technology (IT) development projects from the rare perspective of Indian vendor managers in one of the world's largest IT service companies. It draws on a qualitative study of a collaborative partnership and focuses on the key boundary-spanners that are responsible for developing trustful and sustainable client relationships and coordinating highly complex projects. We analyze vendor managers' narratives of their collaboration with a European client in a long-term project, which is presented as a strategic partnership in an outsourcing 3.0 mode. The study offers a rich and conceptualized account of those managers' boundary-spanning activities and a context-sensitive understanding of their boundary work. The study applies Bourdieu's concept of capital (economic, cultural, social and symbolic) not only in its analysis of the two powerful partners but also in its discussion of the boundary-spanning activities that are reported. The analysis demonstrates the coexistence of transactive and transformative modes of collaboration in the studied case. It reveals both the importance of partner status and the impact of that status on the forms of boundary-spanning activities in which the partners engage. Finally, this study suggests new research questions that will promote an understanding of both transactive and transformative boundary spanning and the reciprocity of boundary-spanning activities between vendor and client in a global collaborative partnership.
\end{abstract}


Key words: Emerging Market MNC, Vendor Perspective, Status Asymmetry, Transformative Mode of Collaboration, Qualitative Research 


\section{Introduction}

For an increasing number of managers in multinational companies that collaborate across the boundaries of their headquarters and foreign subsidiaries, global collaboration has become the norm. Global work has also become increasingly important in the offshore outsourcing context, for example, when employees of large information technology (IT) vendor organizations from India and other emerging economies are located in offices around the world to address the needs of their organizations' major clients. These vendor managers are expected to engage constructively with multiple overlapping boundaries (organizational, regional, national, linguistic and professional); they are the key actors in a successful collaboration.

This paper focuses on interorganizational boundary-spanning activities in the specific context of complex global development projects from the rare perspective of vendor managers, who in this case work for an Indian company that is one of the world's largest IT service providers. Indeed, this global development project is so innovative and strategic for both vendors and clients that it has been showcased in joint press releases and other public statements that describe it both as the most advanced form of outsourcing and as a transformative partnership (Carlile, 2004; Clampit et al., 2015). In this form of collaborative partnership, the relationship is no longer considered to be one of vendor and client, but instead, is one in which vendor's status has changed to that of an ally and an equal partner with the client (Levina \& Vaast, 20I4; Clampit et al., 2015).

Inspired by scholars who have called for context-sensitive studies (e.g., Meyer, Mudambi, \& Narula, 20I I; Hinds et al. 20II), we follow Levina and Vaast (2008) in their attention to capital for the understanding of context, and Ravishankar et al. (20I3) and Ravishankar (20I5) for a non-"Western-centric" stance. In this case study, we draw attention to Indian top and middle vendor managers, who appear to play vital boundaryspanning roles not only between "onsite" and "offshore" teams but also between client and vendor employees. Most of the empirical studies on boundary spanning have examined organizations located in developed countries, investigating either how firms form strategic alliances (e.g., Gulati \& Singh, 1998) or how bicultural managers in subsidiaries act as bridge-builders in multinational corporations' (MNCs) cross-cultural activities 
(e.g., Yagi \& Kleinberg, 20II). The offshore outsourcing research has primarily investigated boundaryspanning activities, including trust building and knowledge sharing (e.g., Jensen, 2012; Zimmermann \& Ravishankar 20I4), from the perspective of powerful (oftentimes Western) client organizations that choose their vendors, set agendas, transfer knowledge and assess the work provided by vendor companies. There are a few exceptions, for instance, Abbott et al. (2010) and Levina and Ross (2003), who explore how global collaboration is experienced by vendor representatives; however, vendors are often not considered equal partners with their clients, as described in Ravishankar et al. (2013). With the growing maturity of offshore service providers, more scholars have shown interest in conducting case studies on the interaction between "onsite" and "offshore" team members, exploring their trustworthiness (Tøth, 2015) and perceptions of each other's competencies, their motivations to share or withhold knowledge, and their commitment to assigned tasks (Zimmermann \& Ravishankar, 2016).

This study adds to the literature on boundary-spanners by investigating the following research question: how do vendor managers engage in interorganizational boundary spanning in a strategic partnership with their clients? More specifically, we investigate how Indian vendor managers collaborate with major Western clients in projects that lead to the transformation of a relationship in which both partners are strong. In addition, we aim to conceptualize the boundary-spanning activities in which the vendor managers engage in the global development of the advanced IT services and strategic business solutions they offer to their clients. By adopting a focus on these (micro)practices and a sensitivity to context, we also shed light on the interdependence of the partners' status and specific boundary-spanning activities and roles.

Building on extensive qualitative material, the case study provides empirical illustrations of the nature of the interorganizational boundary-spanning activities. In addition, it highlights that the boundary-spanning activities seem dependent on the vendor's status vis-à-vis the client. In other words, although both partners are equally powerful and the transformative mode of the boundary spanning is clearly achieved in certain instances, the (micro)practices accounted for in interviews with the vendor managers indicate that the expected power shifts between the partners (Levina \& Vaast, 2005; 2008; 20I4), and the partnership among equals 
that emerges, might not be permanent. Consequently, this case study problematizes the literature's assumptions about the transformative mode of boundary spanning as the pinnacle to reach for both client and vendor. It identifies the impact of potential status differences and questions whether a client will consider a transformative mode of boundary spanning desirable.

The paper is structured as follows. First, we present an account of previous works on boundary spanning and boundary-spanners to explicate the diversity of boundary-spanning activities in which vendor managers engage. This account also clarifies our positioning within the political view of the boundary spanning literature. Second, we explain our research design, present the case and account for the case study methodology. Third, we present our analysis of the (micro) practices of boundary-spanning activities and the client-vendor contexts in which they are embedded to reveal narratives of the close collaboration that is characterized by mutual trust and strong social ties alongside practices that are linked to tenser relationships. Subsequently, we discuss the insights that can be gained from the empirical analysis regarding modes of boundary spanning, and then present new research questions inspired by our study.

\section{Boundary-spanners in global collaboration - a theoretical outline}

The theoretical and empirical research on collaborative partnerships tends to focus on the organizational and institutional levels, for example, in studies of mergers an acquisitions. In recent years the focus has changed from being on Western companies' acquisitions towards multinational companies venturing from emerging markets such as China and India into advanced economies (Xing et al., 2017). Studies of the micro-level with an emphasis on how individual actors interact across organizational boundaries are still scarce. An exception is the work by Liu and Almor (2016), whose qualitative study of the cross-cultural aspects of a supplierentrepreneurship relationship investigates how culture can influence how returnees and local entrepreneurs in China address uncertainty in interorganizational relationships.

In this study, we aim to investigate how boundary-spanners' actions are intertwined with interorganizational collaboration. Therefore, we will first briefly present what is commonly meant by boundary-spanning and 
then focus on the literature streams that investigate boundary-spanners' (micro-)activities, along with the interorganizational dynamics in which they are involved.

\section{Categorizing boundary spanning activities}

The completion of global IT development projects requires the organizational capability to communicate, coordinate, build trust and facilitate collaboration that spans not only geographical and temporal distance but also national, organizational, and professional boundaries (Espinosa et al., 2003; Hinds \& Bailey, 2003; Hinds et al., 20II). Individual boundary-spanners in a client-vendor relationship also have to span radically different knowledge domains and expertise: strong business domain knowledge on the client side (e.g., finance, insurance, accounting) and deep and complex technical knowledge on the vendor side (Tøth, 2015).

In the broadest sense, boundary-spanning is a set of activities, processes and practices that connect entities separated by boundaries. Boundary management originates in information processing theory, which focuses on knowledge as something that can be stored or transferred across a pre-given boundary (Carlile, 2004). Early contributions to organizational theory described the boundary-spanning function as managing the interface between organizations and their environment both through information processing and gatekeeping (Adams, 1976) and through buffering, moderating and influencing external events (Aldrich \& Herker, 1977). During the last two decades, there has been a greater focus on knowledge sharing between and within teams (Kostova \& Roth, 2003; Marrone, 2010), resulting in the establishment of a common understanding through "translation" (Krishna et al., 2004).

\section{The boundary-spanners}

A boundary-spanner can be described as "an actor whose primary job responsibilities involve managing within multi-organizational and multi-sectoral arenas" (Williams, 20I0: 2). A boundary-spanner can be an individual with a dedicated job role or responsibility "to serve as a connection between different constituencies" (Wenger, 1998), for example, a "relationship manager" helping to make strategic alliances work effectively. Studies of global work and "offshore" outsourcing present a clear profile of boundary-spanners. Boundaryspanners can work "onsite" and "offshore" and at various hierarchical levels. Most "onsite" vendor employees 
who work closely with clients have extensive international experience and are very mobile (Abbott et al., 20I0; Søderberg, 2015). Lower-level "onsite” vendor employees are often on short-term assignments to assist clients and acquire client-specific knowledge. On their return to "offshore" locations they are expected to serve as "knowledge mediators" and potential contact persons for client representatives (Krishna et al., 2004; Søderberg et al., 2013).

In his literature review on boundary-spanners in both the public and the private sector, Williams (20I0) highlights skills that characterize boundary-spanners in general: the ability to work in teams, good communication skills to help produce a shared interpretation of goals and agreement on roles and norms, the ability to cultivate and maintain effective interpersonal relationships and the capacity to build reputational confidence and trust (see also Kapur \& McHale, 2005). However, boundary-spanners' lives are often the subject of considerable tension and ambiguity, so they also require networking skills and skills to cope with high levels of complexity. They must be comfortable working with cultural, professional and organizational diversity and overcome an "us and them" mentality. Eventually, they must develop skills in persuasion, negotiation and conflict resolution (Child et al., 2005).

\section{Boundary-spanners' activities}

The literature lists numerous key functions and responsibilities that are undertaken by boundary-spanners. Early in the research, organizational theorists coined the notion of a "gatekeeper" who protects an organization against external threats (Adams, 1976). Scholars who focus on how to improve knowledge management across boundaries highlight the role of boundary-spanner as a "broker" (Dyer et al., 200I) who enables the exchange of information and knowledge sharing among various groups (Kostova \& Roth, 2003). A "bridge builder" connects organizations and people from different cultures and like a diplomat, builds trustful cross-group relationships through negotiations and the management of potential conflicts through careful interventions (Johnson \& Duxbery, 2010). This type of boundary-spanner is considered not only a "translator" between different communities who assists others in interpreting a lesser-known context (for example, between business users and IT experts) but also a "cultural liaison" or "transnational intermediary" 
(Child et al., 2005; Mahnke et al., 2008) whose foreign language skills may further contribute to the establishment of a common cognitive ground (Barner-Rasmussen et al., 20I4). With the ability and sensibility to manage various forms of difference in collaborative arenas, the boundary-spanner can even act as a partner who cultivates a close relationship with external actors based on trust and strong social ties (Sturdy \& Wright, 20II).

The multiple activities in which boundary-spanners are involved have been synthesized in a framework by Palus et al. (20I4), who identify three main boundary-spanning strategies, each of which involves distinct activities. The three main strategies are "managing boundaries" by acknowledging and respecting differences, "forging common ground" by connecting and mobilizing parties to go beyond their differences, and "discovering new frontiers" by transforming the relationship into one that is new and inclusive. The strategy "managing the boundaries" first entails buffering, which defines and clarifies group identities within each group and then creates intergroup safety and protection. Buffering is followed by reflecting, which stands for seeing each side of a boundary and sensitizing each group to the other's values and expertise, thereby discursively employing cultural categories both to make sense of groups' perceived similarities and differences and to effectively manage relations between "offshore" and "onsite" teams (see also Ravishankar, 2015). Reflecting can foster an understanding of these similarities and differences, eventually developing an intergroup respect that paves the way for collaborative work (e.g., Johnson $\&$ Duxbery, 20I0). The strategy of "forging common ground" is achieved through connecting by creating person-to-person linkages and building trust, which is associated with mobilizing where a community and an understanding of common purpose are developed (e.g., Sturdy \& Wright, 20I I; Barner-Rasmussen et al., 20I4). Finally, the strategy of "discovering new frontiers" implies first a weaving, which both advances interdependence and integrates each distinct group into a larger organizational whole. The final stage is transforming, which is accomplished by uniting multiple groups to enable reinvention. Transforming implies continuous interaction across boundaries such as those between vendor and client, questioning the established norms, practices and identities that allow shared perspectives and new directions to emerge (see also Carlile, 2004; Levina \& Vaast, 2005). 
Palus et al.'s (20I4) framework not only presents a detailed synthesis of the various activities in which boundary-spanners engage but also enables the recognition of boundary-spanning activities that correspond to various forms of collaboration. The first two strategies are aligned with collaborations that are "transactional" (Levina \& Vaast, 20I4): the partners collaborate closely but remain in separate groups, each of which builds upon the work of the other. In the third strategy, the relationship enters a "transformative" mode (Carlile, 2004; Levina \& Vaast, 20I4): in other words, new groups are formed across established boundaries and the collaborators both sense an interdependence and engage deeply in work that transforms and redefines existing practices, leading to new joint practices. The transformative relationship tends to be portrayed by Palus et al, (20I4), and also by other scholars as the most advanced form of partnership, and implicitly the most desirable and effective form of collaboration (Carlile, 2004; Levina \& Vaast, 2005; 20I4; Clampit et al., 2015).

\section{Boundary-spanning activities in context}

Although studies of the (micro)practices of boundary-spanning activities enable a rich understanding of what exactly is done in practice, some studies tend to present these activities as disconnected from the larger context in which the collaboration takes place. However, other studies of boundary spanning represent what Carlile (2004) characterizes as a political approach with an emphasis on the partners' different interests (e.g., Nicholson \& Sahay, 200I; Levina \& Orlikowski, 2009; Ravishankar et al., 20I3).

It is not risk-free for the client to offshore service activities. Jensen and Petersen (2013) show that managers who engage in "transformational" global sourcing are pulled out of their comfort zones and must reflect upon their risk perceptions, for example, when a client's strategic knowledge is revealed to vendor employees and they are authorized to explore, invent and develop new products and processes. Through their analysis of micro-processes, Van Marrewijk (20I0), Mahavedan (20II) and Zimmermann and Ravishankar (20I4) reveal how Dutch and German engineers first presented collaborationss with Indian IT consultants as a smooth interactiion and knowledge transfer based on a shared "engineering culture." However, efforts to improve the coordination of knowledge sharing and collaboration stopped when some European engineers 
felt that their jobs were threatened by the equally qualified Indian engineers. Consequently, the Europeans began to blame the Indians for being less competent and trustworthy. Based on an ethnographic study that displays how "Western culture" is discursively mobilized by Indian employees in their sensemaking of collaboration with employees in a European headquarter, Ravishankar (2015) emphasizes that a microanalysis of collaborative practices in a cross-cultural setting must not only reflect inherent tensions between teams. It must also explore how power assymmetries are perceived and cognitively addressed by those involved. Contextual considerations are also proposed by Ravishankar et al. (2013), who highlight the importance of the historic and economic relationship between India and Western countries. From their post-colonial perspective, the authors show how Indian vendor managers engage in practices to compensate for potential power asymmetries, for example, by adopting the front-edge knowledge-management platforms that are used in the US to shed the image of "backwardness" that Western clients tend to project onto them.

In their study of offshoring projects, Levina and Vaast $(2008,20 I 4)$ are also attentive to context and power dynamics. They apply a practice perspective (Bourdieu \& Wacquant, I992) that enables them to acknowledge "the importance of power relations, the role of human agency, and the mutual constitution of institutions and actions" (Levina \& Vaast, 20I4: 286-287). They posit that power relations arise when agents do not have equal access to four fundamental types of capital, which Bourdieu conceptualizes as economic, cultural, social and symbolic capital. An example of economic capital is money to be invested in or received for specific projects, wages, time, and access to technology. Cultural capital can be professional expertise (in this case computer science or domain-specific knowledge within a particular business area), education, English-language proficiency, or ownership of important information. Social capital is formed by networks of interpersonal relationships that are characterized by close and frequent interaction, for example, between various business stakeholders and senior IT managers. Symbolic capital can be the prestige, honor, and attention that can be attributed to each of the three abovementioned forms of capital, for instance, having graduated from a prestigious university or speaking English with an accent that is considered high-status. In some cases, these differences in various forms of capital can lead to a pronounced imbalance of resources between "onsite" and 
"offshore" participants and give rise to status differences and power struggles, thus inhibiting effective collaboration.

This phenomenon is illustrated and conceptualized by Levina and Vaast's (2008) study of a Western financial service firm's offshoring of highly demanding IT development projects to Russia and India. In their study, a lack of economic capital prevented frequent travel and a lack of social capital prevented "offshore" staff from engaging with key managers regarding the allocation of resources or commitment in new projects. However, that study also showed how middle managers, who acted as boundary-spanners, "alleviated" status differences, facilitated effective collaboration, and enabled a shift from a transactive mode that preserves existing relationships and power asymmetry between partners to a transformative mode of collaboration in which both partners' power positions changed. Levina and Vaast (2014: 299) develop this idea further and posit that transformative relationships involve "new practices, forms of capital and power relations".

Few studies that adopt a contextual perspective on a service provider go into the details of the various activities in which boundary-spanners engage. To our knowledge, even fewer studies have investigated the case of a transformative mode of collaborative partnership. In the next part of this paper, we present how we studied the case of a mature outsourcing client-vendor relationship.

\section{Research design, chosen case and methodology}

In this section, we first present some reflections on the chosen method (a qualitative study of a single case) and its potential for theory development. Second, we present the case in more detail, followed by an account of how the research question emerged and the systematic way in which the empirical material was analyzed.

\section{A qualitative study of a single case}

Qualitative methods are increasingly considered in international management for the potential that they present for theory development (Birkinshaw, Brannen \& Tung, 20II; Doz, 20II; Romani et al., 20I I; Welch et al., 20II). By capturing more of the complexity of the studied issues, they have the potential to reveal dimensions that may be overlooked in studies in which a theory is developed through hypothesis testing. Sometimes it is the uniqueness of a single case, not its representativeness, which provides the potential for 
theory building (Lervik, 20I I) when dimensions of individual and organizational behavior that have not yet been conceptualized become salient. In this article, we build on a case study that presents two unique features: the studied business relationship (a global partnership that is characterized by mature outsourcing) and the point of view that is taken (a vendor from an emerging economy).

According to Welch et al. (20II) one way to theorize from case studies is to explain social phenomena and specify the contextual conditions under which they work. A contextualized explanation "often starts with a surprising contrast, triggered by the realization that an observed outcome is different from what had been anticipated, provoking the question, "why not X?" (Welch et al., 20II: 748). In the description of our analytical steps below, we, accordingly, highlight how the perceived mismatch between the narratives of the interviewees (the global collaboration and coordination run fairly smoothly) and the accounts of the extant theory-based empirical research on "offshore" outsourcing (immense challenges in global team-work attributable to sociocultural and linguistic differences and work across time zones), which led us to "a redescription or re-contextualization of the phenomenon" (Welch et al., 20I I: 748). Therefore, we decided to focus on boundary-spanners in the vendor organization and their accounts of the activities through which they bridge and translate between vendor and client. Progressively, we came to think of boundary spanning in a client-vendor relationship as structurally dependent on power and status relations. Therefore, the theory development process in which we engage is neither purely inductive nor deductive: it is essentially abductive (see Alvesson \& Kärreman, 20I I:58).

\section{Case presentation: a strategic partnership seen from an Indian vendor perspective}

Modern modes of organizing work increasingly rely on spanning multiple boundaries in the context of strategic alliances and the outsourcing of products and services. The chosen case study offers an opportunity to illustrate intense boundary-spanning activities that form and facilitate a close vendor-client relationship in the context of a complex global project. In this case, the Indian vendor combines client proximity for close coordination with the distribution of "offshore" teams across multiple time zones to ensure lower costs and establish 24/7 service deliveries (Manning et al., 2015). 
This case is part of a research project that studies communication and coordination challenges in large global software development projects in which the researchers developed close, long-term relationships with both European and Asian IT companies. One of these, which this paper anonymizes as InIT, is an Indian multinational company recognized worldwide as a powerful and knowledgeable provider of sophisticated IT services and solutions. The Indian vendor company was established in the I960s, and like other companies in the Indian IT industry (Sauvant et al., 2010), it moved rapidly into developed countries and now employs more than 300,000 employees worldwide. Most of the company's employees work at various locations in India, but the vendor has a substantial presence in 46 countries and has 60 subsidiaries overall (according to the company website). The reasons for the global distribution of InIT's employees are manifold: although information and communication technologies facilitate virtual collaboration, some IT consultants must be collocated with important clients to improve dialogue and obtain more local and domain-specific knowledge. Moreover, InIT applies a "follow the sun model" (Carmel et al., 20I0), which requires its presence in many time zones to ensure $24 / 7$ delivery of IT services to its clients.

A top InIT manager provided entry to multiple company sites and facilitated access to people who are engaged in three partnerships with Western clients: a European bank, a North American bank and a European insurance company (see Table I). According to this manager, the three complex global projects represent not only the most advanced level of services offshoring and global sourcing but also mature relationships that imply strategic business development and experiential learning both for the client and the vendor.

\section{INSERT TABLE I ABOUT HERE}

The primary empirical material, which was collected during visits to multiple vendor sites between December $201 \mathrm{I}$ and February 20I4, consists of 64 semi-structured, open-ended, face-to-face interviews with a wide range of people in InIT, from senior executives to middle managers to young system developers who represent different hierarchical and professional positions within the multinational company (see Tables I and 2). In the 
next section, we show how our research question emerged from the work with all three of the abovementioned projects. However, in this article, we analyze accounts of boundary-spanning activities within only one of three projects and have chosen the project in which the interviews provided the richest accounts of the issues that we wanted to study. Consequently, all of the empirical illustrations of the interorganizational boundary work are taken from 22 interviews with Indian "onsite" and "offshore" vendor managers who are involved in close collaboration with a major European client, here anonymized as Eurobank. In the final phase of our analytical work, we present the insights gained from InIT's partnership with Eurobank in the context of the entire study. These insights facilitated our understanding of how boundary-spanning activities are embedded in the power dynamics between clients and vendors.

The technical expertise of the interviewees and their international experience (see Table 2) indicate strong similarities between the interviewees' profiles and those that have been previously identified in the literature on boundary-spanners (see Krishna et al., 2004; Mahnke et al, 2008; Abbott et al., 2010). Although boundaryspanners in "offshore" locations can be people in top management who are responsible for accounts, programs and business units, they can also be middle managers and more experienced IT consultants who, because of their previous international experience and extensive experience collaborating with client representatives, have acquired additional knowledge and technical, cross-cultural and communication skills.

\section{INSERT TABLE 2 ABOUT HERE}

Eurobank, which is one of the world's leading financial services institutions, has been one of InIT's major clients for the last I5 years. Based on the successful maintenance and development of products the two companies have gradually developed a trusting relationship to the extent that in press releases and public media InIT is often presented as one of Eurobank's "strategic partners." More than 2,500 InIT employees are working with maintenance and IT development projects for Eurobank. Approximately $85 \%$ of those employees are located in so-called "offshore" teams that are geographically dispersed at various sites in India. 
These teams are sometimes managed virtually by a manager who is situated either in another Indian location or in a foreign country. Other teams are based at low-cost locations such as China, the Philippines and Brazil, and they are part of InIT's back-office development or support structures. InIT also has employees stationed at the "front end" — in this case in London, Frankfurt, Singapore and Sydney — to facilitate daily face-to-face interaction with client representatives.

\section{INSERT FIGURE I ABOUT HERE}

Eurobank may be represented by either locally recruited employees or employees who are expatriated from the headquarters. In other words, the global software development project that we study is truly global and involves a culturally, geographically and organizationally diverse workforce at both the client and the vendor levels. Unfortunately, InIT did not allow us to contact client representatives, although we attempted to explain that it would be beneficial to hear both vendor and client accounts of the collaboration process.

\section{An empirically based and emergent research question}

The research on the "offshore" outsourcing of innovation projects and their organization and management (e.g., Krishna et al., 2004; Doz \& Wilson, 2012) often identifies tremendous difficulties with cross-cultural communication, the sharing of tacit knowledge and trust-building in geographically dispersed and culturally diverse teams. (Hinds et al., 20II; Leonardi \& Bailey, 2008; Mahavedan, 20I I; Zimmermann \& Ravishankar, 2014).

Familiar with this research and expecting such accounts, during its first round of interviews in Bangalore, India, the research team was struck by the fact that the InIT interviewees did not tell any stories about challenges and difficulties in communicating virtually, collaborating across cultural divides, and making tacit knowledge explicit. Indeed, they described the development of a trustful relationship between client and vendor representatives, emphasizing that the transparency of both parties and a strong commitment from top management had paved the way for smooth and successful collaborations across boundaries (Søderberg et al., 
2013). The unexpectedly positive interview accounts from "offshore" vendor representatives drove the team's curiosity to further investigate how the allegedly easy knowledge exchange in global collaborations with the Western client was enabled. Who had done the important boundary work in the specific cases? In what type of activities did the vendor managers engage? Was the collaboration actually that smooth? These interrogations led us to our current research question, which focuses on interorganizational boundary work. In two more rounds of interviews in Bangalore and one round of interviews in London, we approached vendor managers who were deeply involved in activities that aspired daily to further develop the vendor-client relationship and transform it into a strategic partnership (Søderberg et al., 20I3). The interviews with these vendor managers (see Table 2), each of which lasted approximately one hour, were conducted using a narrative inquiry approach (Gertsen \& Søderberg, 20II; Liu, Xing \& Starik, 20I2). The interviews constitute the primary data of this case analysis; they are completed using both company information (corporate communication brochures, press releases, and web publications) and field notes.

\section{Analysis}

Our coding and the further analytical process were iterative: we shifted our attention back and forth between what the interviewees said and what the previous research has reported about global (virtual) collaboration. For simplicity, the data are presented here in a linear path that emphasizes the analysis as an emergent research process.

During the first round of interviews in Bangalore, it became clear that many of the daily work activities described by the interviewees involved spanning multiple boundaries. Some vendor managers, both "onsite" and "offshore," played important roles as bridge-builders, translators and negotiators in relation to the client. Therefore, we decided to go to London and interview vendor managers who were collocated with or at least close to client representatives to better understand their specific tasks and requisite skills. Gradually we realized that the absence of interview accounts of (cross-cultural) communication and coordination challenges did not indicate the absence of tensions in relation to the client representatives. 
After the third round of interviews in Bangalore, we decided to code the interviews related to the collaboration with Eurobank, paying attention to three major themes: "vendor-client relationships," "perceived power differences," and "boundary-spanning activities". We performed the first-order categorization individually and independently and then systematically compared the selected quotes. We discussed each variation in coding (choice of quote, category in which the quote is placed), retaining the quotes on which we both agreed, thus creating a shared categorization.

In a second analytical step, we aimed to refine the categories with the help of the existing theoretical studies. The boundary-spanning practices described by the vendor managers presented a clear fit with the strategies advanced in Palus et al. (20I4). We consequently developed second-order categories for each of their model's six boundary-spanning activities (see Table 5). Subsequently, we examined the content of our "perceived power differences" category. We were attentive to how inequalities between the European client and the Indian vendor were accounted for in the interviews and how the vendor managers attempted to negotiate and enact them. In line with Levina and Vaast (2008), we found Bourdieu's conceptualization of various forms of capital (Bourdieu \& Wacquant, I992) to be a useful framework within which to systematize the interview accounts of perceived differences between the client and vendor (see Table 3).

Our work on the first-category "vendor-client relationships" led us to identify the somewhat contrasting accounts of the partners engaged in a transformative relationship (as described by Carlile, 2004 and Levina \& Vaast, 2014) alongside a narrative of the vendor as closely monitored by the client and placed into competition with other vendors (see Table 4). We derived three new categories: "form of contracts with the client," "control” and "competition."

However, the manner in which these categories were connected remained unclear, leading us to take a third analytical step. We returned to the interviews with vendor managers involved in projects with the two other Western clients and in parallel, we examined documents such as company flyers, advertisements, brochures on specific services, web pages and press releases that were collected during the fieldwork studies. Through this exercise, the importance of notions such as "transparency" (see Table 6) and "strategic partnership" (see 
Table 4) became indicative of the type of relationship in which the vendor and its clients are engaged and that they constantly renegotiate.

In summary, our approach to qualitative research through a case study is driven by two main ambitions: First, we have an interest in preserving the semantic richness of the empirical material through the extensive use of interview quotes, providing readers with insights into how the boundary-spanners talk about, interpret and cope with their tasks in a specific context. Second, we have an interest in describing the patterns of interorganizational boundary work through researchers' categorizations, thereby offering a more structured analytical approach to our research issues. Our approach can be characterized as "semantic-abstract" according to Cornelissen's (2016) model of how various styles of theorizing and choice of qualitative methods are combined to represent and explain managerial and organizational phenomena.

\section{Empirical findings}

We first present the client and vendor in interaction, using Bourdieu's concept of capital. This enables us to show that both partners are powerful actors with strong capital. However, the interviewees' accounts indicate a possible perceived asymmetry. The collaborative and transformative relationship in which InIT says that it is engaged with Eurobank, termed “outsourcing 3.0," is then explicated. Subsequently we analyze the vendor managers' accounts of the boundary-spanning activities in which they engage. The final part of this section adds complementary contextual information to the competitive relationship between the partners.

\section{Two powerful partners}

Western clients who are unfamiliar with outsourcing services to India do not necessarily know that InIT is a giant in India's global IT and business process offshoring sectors and one of the world's largest IT service providers. A global account manager recounts that two major cultural challenges related to some Western clients who are new to "offshore" outsourcing are their negative stereotypes about India as a developing country and their prejudices towards Indians, who are perceived as a homogenous national group: "you need 
to sell the country, you need to talk about the colleagues, who are they, and there will be initial issues with accent, understanding the accent and the different ways that people think in India (...) [and] in the West." (\#8)

This means that at least in the initial phase of collaboration, InIT is not necessarily seen as an equal partner by its Western clients. Negative stereotypes of Indian management and culture, along with perceptions of Indian engineers as less skilled and knowledgeable, tend to pervade (see multiple examples in off-shoring ethnographies: Cohen \& El-Sawad, 2007; Mahadevan, 20II; Ravishankar et al., 2013; Zimmermann \& Ravishankar 2014). Stereotypical images of India and Indians ignore the huge social, economic and cultural changes occurring in India's major cities.

As members of a fast-growing, well-educated middle class, InIT's Indian interviewees are insulted when Western client representatives sometimes treat them as inferior in status and rank despite their strong educational background in computer science, their extensive international experience, and the vendor company's strong brand in the field of global IT services.

Nevertheless, InIT has built a global reputation as an IT service provider based on successful projects with Western clients who were ready to outsource and "offshore" maintenance and R \& D activities, and the company has developed a strong relationship with Eurobank characterized by respect for its key capabilities. A production manager explains that he has heard Eurobank managers commenting several times on their relationship with InIT in the following terms: "if it's a complex project, if you want this to be successful you will give it to $[\mathrm{InIT}]$; they will work with you to ensure that if there are pitfalls they will tell you, or they will work with you to come out of it. So eventually, it will be successful.” (\#4).

In addition to the trust that has been built based on previous demanding development projects, the vendor and client have strengthened their close collaboration and mutual exchange of ideas based on what can be described as their complementary and interdependent capital, which are displayed in Table 3. In sum, both client and vendor in this specific case have a strong profile with equally strong capital (Bourdieu \& Wacquant, 1992). 


\section{INSERT TABLE 3 ABOUT HERE}

\section{An Outsourcing 3.0 relationship}

Eurobank has been involved in offshoring activities for more than two decades, beginning with a captive center in India in the late 1990s. In 2010, after many years of collaboration, InIT and Eurobank signed an ambitious I0-year development contract to transform the global banking platform. In a press release, the president of InIT's financial solutions expressed pride in this recognition and stated: "This stellar partnership with [Eurobank] is a crowning moment for us."

A head of strategic initiatives explains the various modes of outsourcing: "[ with] certain other customers, (...) the maturity level of outsourcing will remain in staff augmentation [outsourcing I.0], or (...) few projects in sort of an out-tasking mode [outsourcing 2.0]. But [with Eurobank], the relationship has also matured (...) It gives us an ability to experiment along with the bank in certain initiatives which possibly nobody would do ever. (...) [For example] we worked along with [Eurobank] in creating this Intellectual Property jointly, which helps us to build the product, gives [Eurobank] what they want; at the same time, it gets us into a commercial model where we can sell it in the market." (\#7).

The descriptions of the Eurobank and InIT relationship provided by the head of the business unit, the head of strategic initiatives, the head of production management, and three middle managers touch upon the key characteristics of transformative modes of relationships, as specified by Carlile (2004) and Levina and Vaast (20I4). Both partners establish common interests, making trade-offs and transforming domain-specific knowledge. The relationship between the partners is negotiated and breaks away from a model in which the vendor is simply answering to the client's requests, as in traditional (or transactional) modes of outsourcing. The partners engage in new practices and the development of new products that will contribute to both the vendor's and the client's future business activities (see Table 4). 


\section{INSERT TABLE 4 ABOUT HERE}

\section{Boundary-spanning activities for global collaborations}

An overview of how this partnership functions in practice is presented in the model of boundary-spanning activities by Palus et al., 20 I4 (op.cit. 2I I-2I6). In Table 5, we briefly present some illustrations of the various activities in which the vendor managers engage when they span organizational boundaries.

The first activity pertains to the management of boundaries and is accomplished in two ways: buffering and reflecting. Vendor managers engage in buffering when, for example, the client demands services that were originally not included either in the contract or in the development scheme. To protect his group's allocation of resources and safety, the manager can step in and set a clear boundary. Another mode of buffering can take the form of placing a person from InIT directly at a client's site, so that this person becomes a privileged interlocutor for both the client and the vendor's team. This establishes a clear boundary between the groups and eases the flow of communication (Leonardi \& Bailey, 2008).

Reflecting activities between InIT and Eurobank can draw on general knowledge about cultural differences in the form of communication practices across countries or across sites, where a vendor representative can serve as a cultural mediator who facilitates intergroup cultural or linguistic understanding (see also Liu \& Almor, 2016). InIT also uses the strategy of posting some of their employees "onsite" on short-term assignments so that they can gain a rich understanding of the clients' conditions and needs that they can subsequently convey to the "offshore" team.

\section{INSERT TABLE 5 ABOUT HERE}

The second type of activity aims to forge common ground. It is achieved through the practices of connecting and mobilizing. Connecting is actively done between InIT and Eurobank, not only with "onsite" teams but also through frequent visits to "offshore" sites and intense interactions between client representatives and 
vendor employees, for example, at workshops in which the requirements of a subproject are discussed in detail. This enables both partners' teams to simultaneously bridge cultures and locations. Eurobank's visits to "offshore" sites create personal relationships and contribute to the creation of trust: names are given to faces, different working conditions and time-zone differences become tangible. Connections between the client organization and "offshore" members of InIT can also be achieved by developing routines such as allocating particular periods of a working day to videoconferences or communicating through chat functions.

Mobilizing is achieved, for example, by involving partners in interactions to build a common platform. Client managers who appear at town-hall meetings to tell "offshore" teams about future goals and to praise the work that has already been done also contribute to developing a sense of community. Mobilizing can be done by pulling in additional resources either from internal experts with a specific and rare skill set or from external consultants on specific projects. A global account manager describes the advantages of rotating experienced computer engineers in the vendor organization across sites. This commitment to providing the client with specific knowledge also contributes to creating a sense of shared goals and community between the partners.

A third set of activities aims to discover new frontiers through "weaving" and "transforming." Weaving practices include, for example, building up strategic teams composed of experts from both the client and the vendor. This implies the risk of disclosing important information from both sides. However, the interviewed vendor managers described how as boundary-spanners, they sometimes need to remind Eurobank representatives that the success of the development project in which they are engaged is dependent on both partners' willingness to reveal and transfer strategic knowledge across boundaries (see also Jensen \& Petersen, 2013).

Transforming practices take place when the client and vendor achieve a mature form of partnership. For example, involvement in large programs (e.g., changing the global banking platform in 30 countries in which the client is active) requires the vendor not only to deliver what is expected but also to co-develop and invent new solutions to unanticipated matters. These practices may result in new products that strengthen the 
partners' respective market positions as a world-leading bank with a broad portfolio of products and services and as a global IT provider of leading-edge solutions to the financial sector.

\section{Vendors in competition}

InIT is on Eurobank's list of top strategic partners and preferred vendors. In some cases, however, four or five vendors are asked to collaborate and compete for new business. In practice, it seems that only a few key strategic projects are delivered with a sole vendor, as a global account manager explains: "For a particular project when the customer says I want to work with you and $\mathrm{X}$ who are competitors (...). So we both collaborate, it's a routine practice, we collaborate on operational things, on strategic aspects, and sometimes it so happens that someone from our team is put as the head of both, and he is supposed to look at both partners equally $(\ldots)$ so his job will be to foster collaboration between the two competitors." (\#8)

These collaborative practices place the vendors' teams into a competitive-collaborative situation in which vendors can be benchmarked against each other. As an engagement manager in InIT underscores, the client thus becomes less dependent on a sole vendor, thereby enhancing supply security: "from the [Eurobank] point of view [it is] a very good way of managing risks. (...) But in these kinds of scenarios they know both these vendors are on their toes and the client can dictate the terms." (\#5)

This arrangement with multiple vendors thus questions InIT's understanding of the relationship to the client as a partnership because it reproduces the conventional vendor-client relationship even though InIT is still among the most highly recognized providers of IT services in the world, and the client depends on it to maintain and further develop its core business.

\section{Transparency}

The Indian vendor managers describe the close and intertwined partnership in which InIT employees sit with Eurobank employees at the "offshore" locations such as Bangalore and Chennai and at the "onsite" locations such as London, Frankfurt, Singapore and Sydney. A common theme is the necessity of transparency in the processes that are in place, the organization of staff, and how projects are proceeding and the challenges that must be met: "Transparency is a single word but it means a lot, so transparency in terms of organization 
structure, transparency in terms of how you are structuring the work, transparency in terms of how you are sharing the progress, transparency in terms of the people, who are the key people" (\#4). Table 6 presents four dimensions of this transparency. In the interviews, the theme of transparency was frequently linked to the concern of establishing trust between the client and the vendor: "If as a vendor partner leader I can't explain what are the mechanisms I have in place, what are the reports in place, what you can verify as a factual artefacts, then [the client] will never believe me” (\#4).

\section{INSERT TABLE 6 ABOUT HERE}

InIT's focus on demonstrating transparency and accountability is also present both on the company website and in brochures and magazines from the firm's corporate communications and public relations departments. However, an InIT global account manager mentions that he would like Eurobank to be much more transparent and explicit in its communication to its suppliers, not least to improve the exchange of domainspecific and tacit knowledge: "I think of transparency (...) how do you create a level playing field for all the suppliers? How do you give all messages or all the information data that is required for the supplier to do the job? Those kinds of things are where I would like to influence [the client].” (\#8)

There seems to be an asymmetry: clients demand transparency, which the vendor is willing to offer at many levels. For strategic reasons, however, Eurobank does not necessarily aim to be as transparent with InIT and its other service providers. The client decides which vendor should work on which parts of a product and only the client has an overview of the entire development process and the tools and technologies developed by various vendors. Accordingly, there is an imbalance of knowledge and difficulties related to the information flow from the client to the vendor.

To summarize the key contextual elements of the InIT and Eurobank relationship, one can advance that the relationship is a mature one in which InIT belongs to Eurobank's preferred vendors; however, it is also a partnership in which the client can "dictate" its terms. Even when InIT managers proudly present this 
collaborative project as "outsourcing 3.0" and a transformative mode of relationship in which the partners challenge each other, the client retains areas in which it can pressure all of its vendors. The transparency that InIT insists upon offering can be seen as both a guarantee of high quality and the possibility for the client to exercise control.

\section{Discussion}

Using the framework of Palus et al. (2014), we could identify the various boundary spanning strategies and practices. We see not only how vendor managers step in to protect their company's interests and intergroup safety (buffering) but also how they foster understanding between cultures (reflecting). We learn how they find practical solutions to bridge time zones (connecting) and create a sense of community and shared goals (mobilizing). Finally, we hear how the partners sit together to develop new tools (weaving) and assist each other in creating new products that can strengthen their positions in the global market (transforming). Focusing exclusively on the vendor company's narrative of the transformative mode of this so-called outsourcing 3.0 relationship without consideration of the various organizational contexts gives the impression of an unproblematic client-vendor partnership. However, the number and detail of transactive boundaryspanning activities (to manage boundaries and forge common ground), the transparency requested by the client, and InIT's status as a preferred vendor in constant competition with other IT service providers, blur the proposed narrative.

When InIT managers buffer between the client and their own organization, their actions can be interpreted as protection of their interests against the client's increasing demands and strategic use of competitors. When InIT managers explain European modes of thinking or communicating to their Indian employees (see also Liu and Almor, 2016, on cultural understanding in interorganizational relationships), they are illustrating a reflecting strategy to promote intergroup knowledge and cross-cultural understanding. However, one wonders whether there is an acute need to "reflect" because to retain business, vendor managers must constantly adapt to the numerous demands of various client representatives at multiple client sites worldwide. The InIT 
managers who serve as key boundary-spanners both "onsite" and "offshore" provided multiple illustrations of their cross-cultural interaction skills in spanning interorganizational boundaries (Søderberg, 2015). It remains an open question as to whether the Eurobank representatives who play similar roles as boundary-spanners towards the vendors invest equally in learning about preferred management and communication styles in an Indian business context. In view of the practices of managing boundaries, InIT appears to retain the status of a vendor organization that must respond to client demands. In addition, it could be that some Eurobank employees assign a lower status to InIT employees. This could also explain the vendors' constant use of "reflecting" practices. The lived experience of the "offshore" staff in other outsourcing projects in India provides rich testimony of how employees constantly fight the projected image of backwardness (see Cohen \& El-Sawad, 2007; Ravishankar et al., 2013; Ravishankar, 2015).

In addition, the strategy of "connecting," which consists, for example, of bringing client and vendor representatives together during visits at "onsite" or "offshore" locations, also appears in a different light in view of other clients' perceptions of Indian IT employees as occupying a lower status while posing a potential threat to Western engineers due to their strong intellectual capital (Mahadevan, 20II; Metiu, 2006; Zimmermann \& Ravishankar 2016). From this perspective, Eurobank's frequent visits to "offshore" offices can also be understood as a form of risk control (Aron et al., 2005; Jensen \& Petersen, 2013). Indeed, the client not only achieves a much deeper understanding of processes and products by participating in numerous joint workshops but also gains stronger control over the vendor through its physical presence at the vendor's facilities. InIT's insistence on offering transparency can be seen both as an answer to the client's need for control and a need to improve the Indian company's trustworthiness in Western eyes.

Furthermore, InIT's narrative of being in an outsourcing 3.0 relationship is contradicted by the system whereby Eurobank operates with a set of preferred vendors that are in constant competition. This is clearly articulated by InIT managers as a way to pressure the vendors ("vendors are on their toes and the client can dictate the terms"). Rottman's (2008) study of "offshore" supplier networks associates the practice of multiple preferred vendors as a way for the client to strengthen its social capital as it increases both social ties 
and local networks. Simultaneously, it can be seen as potentially lowering the unique intellectual capital of a particular vendor whose expertise is exposed to its competitors.

In sum, the detailed analysis of the boundary-spanning activities that take place in this client-vendor partnership indicates that contextual dimensions seem to affect the practices in a manner that is not expected in the literature. In our case, middle managers do not alleviate status differences (as claimed by Levina $\&$ Vaast, 2008); instead, they seem to be compensating for status differences. Status and power imbalance between the partners of a supposedly transformative relationship remain similar to that of a transactive relationship, as demonstrated by the widespread practice of "managing boundaries." Although the clientvendor relationship evolves between outsourcing I.0 and 3.0 modes, the client seems to employ strategies to maintain its advantageous power position and retain its vendor in a predominantly transactional relationship by pressing competition and forms of control (transparency). In other words, the collaborative partnership in which these two powerful organizations are engaged may not have changed the vendor's status very much, at least not with respect to the micro-practices of boundary spanning.

\section{Contribution to the existing research and further studies}

The study of the EuroBank-InIT case makes contributions to the research in several ways. First, it offers an empirical contribution to the understudied issues of transformative relationships as seen from the rare perspective of a vendor in an emerging economy (see also Abbott et al., 2010; Ravishankar et al., 2013; Ravishankar 2015). Second, the study combines a contextual perspective on potential status and power asymmetries with a detailed account of boundary-spanners' concrete interorganizational activities. Our third contribution is the problematization (Alvesson \& Sandberg, 20II) of the assumptions in the literature on boundary-spanning activities in the transformational mode. Previous studies have shown boundary-spanning activities primarily as a method of overcoming or alleviating (status) differences (see Palus et al., 20I4; Levina \& Vaast, 2008; Ravishankar et al., 2013), implicitly assuming the achievement of equal stances between the

partners when they engage in the co-development of design and the implementation of innovations. Ravishankar (20I5) goes further by investigating how "offshore" organizational members, who often suffer 
from imposed status asymmetries, discursively frame perceived cultural differences between "offshore" and "onsite" in constructive ways that reconcile and realign disputing teams, stabilizing their mutual relationships. In our case study of what vendor managers describe as a transformative mode of collaboration, it appears that despite the Indian multinational vendor's very powerful position (cf. the capital analysis), some status differences between client and vendor remain. Because of this status asymmetry, vendor managers must engage deeply in all types of boundary-spanning activities, somewhat challenging the imagery of a true partnership with mutual trust and strong social ties. We therefore see status (asymmetry) as constitutive of boundaryspanning activities in the sense that it influences the activities in which vendor managers engage and how; this appears to be true even in the case of what the companies themselves have termed a strategic collaborative partnership. In other words, boundary-spanning activities are linked not only to the boundaries that are spanned but also to the status differences between the partners.

Our case study contributes three additional insights. First, boundary-spanning activities in offshoring projects have often been studied in relationships of strong power asymmetry, mostly from the client's perspective. Studying collaboration between two very strong partners, the theme of status asymmetry remains. The case study indicates that it may be more important for the vendor to engage in certain boundary-spanning activities (e.g., protecting its own interests and adapting to the client's requirements using strategies such as buffering, reflecting, connecting or even mobilizing, see Table 5). The fact that the present case is vendor-centered suggests the following new research questions: how do boundary-spanning activities differ for the partners involved? Are there any strategies that do not need to be reciprocal, in which it is sufficient for one partner to engage and thus to adapt to the other (for example, by reflecting)? Further studies of collaborative partnership could investigate the reciprocity of boundary-spanning activities.

Second, a transformative mode of relationship tends to be presented in the form of the most advanced boundary-spanning activities and thus implicitly as the most desirable form. However, in a client-vendor relationship, a more stable transformative mode will reduce the powerful status of the client, tending to pull the client out of its comfort zone into situations that represent various risks, as identified by Jensen and 
Petersen (2013). Our case study shows how the client organization develops strategies to remain in the most advantageous position, placing its vendors in constant competition, thereby increasing its own social capital and potentially lowering the unique intellectual capital of each of its competing and collaborating vendors. Consequently, another research venue could be the study of partners' motivations for entering into transformative relationships in global outsourcing. Is the transformative mode always seen by all partners as desirable? Could the transformative mode be more desirable for the partner in a lower status position? Do vendors ponder the benefits and costs of entering into a transformative relationship and if the answer is yes, how do they do so?

Third, transformative relationships are also presented both as the end-state of the process of boundaryspanning activities (e.g., Palus et al., 20I4; Levina \& Vaast, 20I4) and as the highest stage of outsourcing (Clampit et al., 2015), in which business is redefined because trusted vendors are considered to be allies and strategic partners when they help clients innovate and learn and thereby undergo transformative change. However, in the description of the various boundary-spanning activities in which the vendor engages, many activities linked to transactive forms of relationship remained present in the studied case. The literature posits that transactive forms precede transformative forms. However, in the case study, the two forms seem to coexist. This points to another area of future investigation: do transformative modes of collaboration really supplant transactive ones, or do they coexist?

\section{Conclusion}

By considering the rich material about a global software development project from the less-studied perspective of an emerging market vendor engaged in a transformative mode of collaboration, this case study enabled us to create more than an empirical illustration of interorganizational boundary-spanning activities. We have shown how vendor managers draw upon both their multifaceted skills and their international and cross-cultural experiences when they play key roles as boundary-spanners both in negotiating client relationships and in 
bridging and coordinating complex processes and products. The study of these boundary-spanners' multifaceted practices also provides information about the contextual issues that affect their boundary work. Despite the advanced level of cooperation between the partners, despite the size and reputation of the Indian vendor as a global player in the IT services industry, and despite the importance of its services for the client's competitiveness at a global market, its lower status as a vendor affects its managers' boundary-spanning activities with respect to the client. Consequently, this case highlights the need to consider contextual issues, the specific type of partnership, and the perceived status of the partners involved in global collaboration and innovation to better grasp the dynamics of interorganizational boundary work. Our empirical study thus led to the problematization of assumptions (Alvesson \& Sandberg, 20II) in the literature on boundary-spanning activities around the themes of reciprocity, desirability and end goal.

In summary, we adopted the less-studied perspective of an Indian vendor engaged in long-term projects with Western clients. This provided a complex case that helped us both to reconsider the pervasive views of boundary-spanning activities and to offer a contextualized explanation of the vendor's ambition to reach a transformative mode of collaboration, the client's forms of resistance and thus the instability of this transformative mode of partnering.

\section{Acknowledgments}

The empirical study was conducted together with S. Krishna and Pernille Bjørn within the context of the research project Next Generation Technologies and Processes for Global Software Development, a project financially supported by the Danish Council for Strategic Research. Laurence Romani acknowledges support from the Department of Intercultural Communication and Management, Copenhagen Business School, for a research stay funded by the Carl Silfvén Foundation (Sweden) that enabled the close collaboration between the authors. We thank the three anonymous reviewers and the special issue editors for their constructive comments. 


\section{References}

Abbott, P., Zheng, Y., Du, R., \& Willcocks, L. (2010). From Boundary Spanning to Creolization: Crosscultural Strategies from the Offshore Provider's Perspective. AMCIS 2010 Proceedings, Paper 274.

Adams, J. (1976). The structure and dynamics of behavior in organizational boundary roles. In Dunnette, M (Ed.) Handbook of Organizational and Industrial Psychology. Chicago: Rand McNally, I I75-I I99.

Aldrich, H. E. \& Herker, D. (1977). Boundary Spanning Roles and Organizational Structure. Academy of Management Review, 2, 217-230.

Alvesson, M. \& Kärreman, D. (20I I). Qualitative Research and Theory Development. Mystery as Method. London: Sage.

Alvesson, M. \& Sandberg, J. (20II). Generating Research Questions through Problematization. Academy of Management Review. 36, 2, 247-27I.

Andrews, T. \& Chompusri, N. (200I). Lessons in 'cross-vergence': Restructuring the Thai subsidiary corporation. Journal of International Business Studies, 32, I, 77-94.

Aron, R., Clemons, E. K., \& Reddi, S. (2005). Just right outsourcing: understanding and managing risk. Journal of Management Information Systems, 22, 2, 37-55.

Barner-Rasmussen, W., Ehrnrooth, M., Koveshnikov, A., \& Mäkelä, K. (20I4). Cultural and language skills as resources for boundary spanning within the MNC. Journal of International Business Studies, 45, 7, 886-905. Birkinshaw, J., Brannen, M. \& Tung, R. (20II). From a distance and generalizable to up close and grounded: Reclaiming a place for qualitative methods in international business research. Journal of International Business Studies, 42, 573-58I.

Bourdieu, P. \& Wacquant, L. (1992). An Invitation to Reflexive Sociology. University of Chicago Press: Chicago.

Carlile, P.R. (2004). Transferring, Translating, and Transforming: An Integrative Framework for Managing Knowledge across Boundaries. Organization Science, I5, 5, 555-568. 
Carmel, E., Espinosa, J.A., \& Dubinsky, Y. (2010). Follow the Sun: Workflow in global software development: Conceptual foundations. Journal of Management Information Systems, 27, I, 17-37.

Child, J., Faulkner, D., \& Tallman, S. (2005). Cooperative Strategy: Managing Alliances, Networks, and Joint Ventures. Oxford: Oxford University Press.

Clampit, J., Kedia, B., Fabian, F., \& Gaffnery, N. (2015). Offshoring satisfaction: The role of partnership credibility and cultural complementarity. Journal of World Business, 50, I, 79-93.

Cohen, L. \& El-Sawad, A. (2007). Lived experiences of offshoring: An examination of UK and Indian financial service employees' accounts of themselves and one another. Human Relations, 60, 8, I235-I262. Cornelissen, J.P. (2016). Preserving Theoretical Divergence in Management Research: Why the Explanatory Potential of Qualitative Research Should Be Harnessed Rather than Suppressed. Journal of Management Studies, on-line first.

Doz, YL. (20II). Qualitative research for international business. Journal of International Business Studies, 42, 582-590.

Doz, Y.L. \& Wilson, K. (20I2). Managing Global Innovation. Framework for Integrating Capabilities around the World. Boston: Harvard Business Review Press.

Dyer, J.H., Kale, P., \& Singh, H. (200I). How to make strategic alliances work. MIT Sloan Management Review, 42, 4, 37-43.

Espinosa, J.A., Cummings, J.N., Wilson, J.M., \& Pearce, B.M. (2003). Team Boundary Issues across Multiple Global Firms. Journal of Management Information Systems, 19, 4, I57-I90.

Gertsen, M.C. \& Søderberg, A.-M. (20II). Intercultural Collaboration Stories. On Narrative Inquiry and Analysis as Tools for Research in International Business. Journal of International Business Studies, 42, 6, 765 786.

Gulati, R. \& Singh, H. (1998). The Architecture of Cooperation: Managing Coordination Costs and Appropriation Concerns in Strategic Alliances. Administrative Science Quarterly, 43, 4, 78I-8I4. 
Hinds, P.J. \& Bailey, D. E. (2003). Out of Sight, Out of Sync: Understanding Conflict in Distributed Teams. Organization Science, 14, 6, 615-632.

Hinds, P.J.; Liu, L., \& Lyon, J.B. (20I I). Putting the global in global work: An intercultural lens on the process of cross-national collaboration. Academy of Management Annals, 5, I-54.

Jensen, P.D.Ø. (20I2). A passage to India: A dual case study of activities, processes and resources in offshore outsourcing of advanced services._Journal of World Business, 47, 2, 3 I I-326.

Jensen, P. D. Ø., \& Petersen, B. (2013). Global sourcing of services: Risk, process, and collaborative architecture. Global Strategy Journal, 3, I, 67-87.

Johnson, K. L. \& Duxbury, L. (2010). The view from the field: A case study of the expatriate boundaryspanning role. Journal of World Business, 45, I, 29-40.

Kapur, D. \& McHale, J. (2005). Sojourns and software: Internationally mobile human capital and high-tech industry development in India, Ireland, and Israel. In Arora, A. \& Gambardella, A. (Eds.): From Underdogs to Tigers: The Rise and Growth of the Software Industry in Some Emerging Economies. Oxford: Oxford University Press, 236-274.

Kostova, T. \& Roth, K. (2003). Social capital in multinational corporations and a micro-macro model of its formation. Academy of Management Review, 28, 2, 297-317.

Krishna, S., Sahay, S., \& Walsham, G. (2004). Cross-cultural Issues in Global Software Outsourcing. Communications of the ACM, 47, 4, 62-66.

Leonardi, P. M. \& Bailey, D. E. (2008). Transformational Technologies and the Creation of New Work Practices: Making Implicit Knowledge Explicit in Task-based Offshoring. MIS Quarterly, 32, 2, 4I I-436. Lervik, J. E. B. (20I I). The single MNC as a research site. In Piekkari, R. \& Welch, C. (Eds.) Rethinking the case study in international business and management research. Cheltenham: Edward Elgar, 229-250. Levina, N. \& Orlikowski, W.J. (2009). Understanding Shifting Power Relations within and across Organizations: a Critical Genre Analysis. Academy of Management Journal, 52, 4, 672-703. 
Levina, N. \& Ross, J.W. (2003). From the Vendor's Perspective: Exploring the Value Proposition in Information Technology Outsourcing. MIS Quarterly, 27, 3, 33I-364.

Levina, N. \& Vaast, E (2005). The Emergence of Boundary Spanning Competence in Practice: Implications for Implementation and Use of Information Systems. MIS Quarterly, 29, 2, 335-363. Levina, N. \& Vaast, E. (2008). Innovating or Doing As Told? Status Differences and Overlapping Boundaries in Offshore Collaboration. MIS Quarterly, 32, 2, 307-332.

Levina, N. \& Vaast, E. (2014). A Field-of-Practice View of Boundary-Spanning in and across Organizations: Transactive and Transformative Boundary-Spanning Practices. In Langan-Fox, J. and Cooper, C.L. (Eds.), Boundary Spanning in Organizations: Network, Influence and Conflict. New York: Routledge, 285-307. Liu, Y, Xing, Y, \& Starik, M. (2012). Storytelling as Research Method: a West-Meets-East Perspective. In Wang, L., Ketchen, D.J., \& Bergh, D.D. (Eds.), West Meets East. Building Theoretical Bridges. Research Methodology in Strategy and Management. Emerald Group Publishing Ltd., I43-I7I.

Liu, Y. \& Almor, T. (2016). How culture influences the way entrepreneurs deal with uncertainty in interorganizational relationships: The case of returnee versus local entrepreneurs in China. International Business Review, 25, I, 4-I4.

Mahadevan, J. (20I I). Engineering culture(s) across sites: Implications for cross-cultural management of emic meanings. In Primecz, H.; Romani, L., \& Sackmann, S. (Eds.), Cross-cultural management in practice: Culture and negotiated meanings. Cheltenham: Edward Elgar, 89-100.

Mahnke, V., Peters, S., \& Bjørn-Andersen, N. (2008). Offshore Middlemen: Transnational Intermediation in Technology Sourcing. Journal of Information Technology, 23, I, I8-30.

Manning, S., Larsen, M.M., \& Bharati, P. (2015). Global delivery models: The role of talent, speed and time zones in the global outsourcing industry. Journal of International Business Studies, 46, 850-877.

Marrone, J.A, (2010). Team boundary spanning: A Multilevel Review of Past research and Proposals for the Future. Journal of Management, 36, 4, 9 I I-940. 
Metiu, A. (2006). Owning the Code: Status Closure in Distributed Groups. Organization Science, I7, 4, 4I8435.

Meyer K., Mudambi, R., \& Narula, R. (20I I). Multinational Enterprises and Local Contexts: The Opportunities and Challenges of Multiple Embeddedness. Journal of Management Studies, 48, 2, 235-252. Nicholson, B. \& Sahay, S. (200I). Some political and cultural issues in the globalization of software development: case experience from Britain and India. Information and Organization, II, 25-43. Palus, C.J., Chrobot-Mason, D.L., \& Cullen, K.L. (20I4). Boundary-Spanning Leadership in an Interdependent World. In Langan-Fox, J. \& Cooper, C.L. (Eds.), Boundary Spanning in Organizations: Network, Influence and Conflict. New York: Routledge, 206-229.

Ravishankar, M.N. (2015). The realignment of offshoring frame disputes (OFD): An ethnographic 'cultural' analysis. European Journal of Information Systems, 24, 3, 234-246.

Ravishankar, M.N., Pan, S.L., \& Myers, M.D. (2013). Information technology offshoring in India: a postcolonial perspective. European Journal of Information Systems, 22, 387-402.

Romani, L. Primecz, H., \& Topcu, K. (20II). Paradigm interplay for theory development: a methodological example with the Kulturstandard method. Organizational Research Methods, I4, 3, 432-455.

Rottmann, J. W (2008). Successful knowledge transfer within offshore supplier networks: a case study exploring social capital in strategic alliances. Journal of Information Technology, 23, 3I-43.

Sauvant, K.P., Pradhan, J.P., Chatterjee, A., \& Harley, B. (2010). The Rise of Indian Multinationals. Perspectives on Indian Outward Foreign Direct Investment. New York: Palgrave-Macmillan.

Sturdy, A. \& Wright, C. (20I I). The Active Client: The Boundary-Spanning Roles of Internal Consultants as Gatekeepers, Brokers and Partners of Their External Counterparts. Management Learning, 42, 5, 487-505. Søderberg, A.-M. (20I5). Indian Boundary Spanners in Cross-Cultural and Inter-Organizational Teamwork: An Account from a Global Software Development Project. In Holden, N., Michailova, S., \& Tietze, S. (Eds.) Routledge Companion of Cross-Cultural Management, London and New York: Routledge, 334-343. 
Søderberg, A.-M., Krishna, S., \& Bjørn, P. (2013). Global Software Development: Trust, Commitment and Cultural Sensitivity in Strategic Partnerships. Journal of International Management, I9, 4, 347-36I.

Tøth, T. (2015). Trustworthiness: Enabling Global Collaboration - An Ethnographic Study of Trust, Distance, Control, Culture and Boundary Spanning within Offshore Outsourcing of IT Services. PhD Series 03. 2015, Copenhagen Business School, Copenhagen.

Van Marrewijk, A.H. (20I0). Situational Construction of Dutch - Indian Cultural Differences in Global IT Projects. Scandinavian Journal of Management, 26, 4, 368-38I.

Welch, C., Piekkari, R., Plakoyiannaki, E., \& Paavilainen-Mäntymäki, E. (20I I). Theorising from case studies: Towards a pluralist future for international business research. Journal of International Business Studies, 42, 740-762.

Wenger, E. (1998). Communities of Practice: Learning, Meaning, and Identity. Cambridge: Cambridge University Press, I998.

Williams, P. (2010). Special Agents. The Nature and Role of Boundary Spanners. Paper to the ESRC Research Seminar Series 'Collaborative Futures: New Insights from Intra- and Inter-Sectoral Collaborations'. University of Birmingham.

Xing, Y., Liu, Y., Tarba, S., \& Cooper, C. L. (2016). Servitization in Mergers and Acquisitions: Manufacturing Firms Venturing from Emerging Markets into Advanced Economies. International Journal of Production Economics, Online first 6 Dec.

Yagi, N. \& Kleinberg, J. (201 I). Boundary work: An interpretive ethnographic perspective on negotiating and leveraging cross-cultural identity. Journal of International Business Studies, 42, 629-653.

Zimmermann, A., \& Ravishankar, M.N. (2016). A systems perspective on offshoring strategy and motivational drivers amongst onshore and offshore employees. Journal of World Business, 5I, 4, 548-567. Zimmermann, A., \& Ravishankar, M.N. (20I4). Knowledge transfer in IT offshoring relationships: The roles of social capital, efficacy and outcome expectations. Information Systems Journal, 24, 2, 167-202. 
Table I: Overview of interviews performed between December 20 II and February 20 I4.

\begin{tabular}{|c|c|c|}
\hline Client organizations & Offshore & Onsite \\
\hline Eurobank & 17 & 5 \\
\hline European insurance company & I5 & 7 \\
\hline North American bank & 20 & 0 \\
\hline Total & 52 & $\mathrm{I} 2$ \\
\hline
\end{tabular}


Table 2: Interviews with vendor managers and employees collaborating with Eurobank

\begin{tabular}{|c|c|c|c|c|c|}
\hline $\begin{array}{l}\text { Inter- } \\
\text { viewee }\end{array}$ & Position & $\begin{array}{l}\text { Years in } \\
\text { InIT }\end{array}$ & $\begin{array}{l}\text { Time of } \\
\text { interview }\end{array}$ & Location & Additional information \\
\hline (9) & $\begin{array}{l}\text { Top manager I) in } \\
\text { banking \& financial } \\
\text { services }\end{array}$ & 23 years & Dec 20II & Bangalore & $\begin{array}{l}\text { Worked for a US multinational in the US and the UK before } \\
\text { joining InIT. } \\
\text { Shares his time between US and India on a monthly basis, } \\
\text { with visits to Singapore, Sydney, London and Frankfurt on a } \\
\text { quarter-annual basis. } \\
\text { In charge of } 26,000 \text { employees. }\end{array}$ \\
\hline \multirow[t]{3}{*}{$(I, 2,3)$} & Delivery manager & $\begin{array}{l}\text { I3 years } \\
\text { 2) }\end{array}$ & Dec 20II & Bangalore & \multirow{3}{*}{$\begin{array}{l}\text { Worked for a European MNC before joining InIT. } \\
\text { Has worked in the US for InIT. } \\
\text { Is in daily or weekly contact with various client } \\
\text { representatives. }\end{array}$} \\
\hline & Services head & & Jan 2013 & Bangalore & \\
\hline & Program manager & & Feb 2014 & Bangalore & \\
\hline \multirow{3}{*}{$\begin{array}{l}\text { (I0, II, } \\
\text { I2) }\end{array}$} & Solution consultant & I5 years & Dec 20II & Bangalore & \multirow{3}{*}{$\begin{array}{l}\text { Worked in a bank in India before joining InIT. } \\
\text { Visits client representatives for kick-offs and meets with them } \\
\text { "offshore" for two-three weeks workshop to discuss } \\
\text { requirements. }\end{array}$} \\
\hline & Testing lead & & Jan 2013 & Bangalore & \\
\hline & Product specialist & & Feb 2014 & Bangalore & \\
\hline \multirow[t]{2}{*}{$(\mathrm{I} 3, \mathrm{I} 4)$} & Team head & 3 years & Jan 2012 & Bangalore & \\
\hline & Development lead & & Jan 2013 & Bangalore & \\
\hline \multirow[t]{2}{*}{$(\mathrm{I} 5, \mathrm{I} 6)$} & Senior developer & 5 years & Jan 2012 & Bangalore & \multirow[t]{2}{*}{ Leader of 25 -person team. } \\
\hline & Senior Developer & & Jan 2013 & Bangalore & \\
\hline \multirow[t]{2}{*}{$(17,18)$} & Developer & 7 years & Jan 2012 & Bangalore & \multirow{2}{*}{$\begin{array}{l}\text { Weekly interactions with client representatives based on } \\
\text { progress reports. } \\
80 \text { people (and I0 module leads) working under him in India. }\end{array}$} \\
\hline & Development lead & & Jan 2013 & Bangalore & \\
\hline (19) & Project manager & II years & Feb 2014 & Bangalore & $\begin{array}{l}\text { Worked } 8 \text { years in Germany for another IT service provider. } \\
21 / 2 \text { years in Singapore working for InIT. }\end{array}$ \\
\hline$\overline{(20)}$ & IT architect & 5 years & Feb 2014 & Bangalore & Close client contact on a daily or weekly basis. \\
\hline
\end{tabular}




\begin{tabular}{|l|l|l|l|l|l|}
\hline (2I, 22) & Global Program director & 22 years & Dec 20I2 & Bangalore & $\begin{array}{l}\text { In charge of multiple strategic projects in the business unit, } \\
\text { among them the Eurobank project. } \\
\text { Was once based in Frankfurt and is now based in Chennai, } \\
\text { but travels between various Indian sites and Singapore. }\end{array}$ \\
\cline { 2 - 6 } & Global Program director & & Feb 20I4 & Bangalore \\
\hline$(4)$ & $\begin{array}{l}\text { Client partner and global } \\
\text { head of production } \\
\text { management and } \\
\text { information security }\end{array}$ & I5 years & Dec 20I2 & London & $\begin{array}{l}\text { Worked for InIT 7 years in the US, 2 years in Singapore, and } \\
\text { 2 years in the UK. } \\
\text { In charge of 600 employees. } \\
\text { Daily contact with Eurobank client representatives. }\end{array}$ \\
\hline$(5)$ & Engagement manager & I2 years & Dec 20I2 & London & $\begin{array}{l}\text { Daily contacts with Eurobank client. } \\
\text { Has worked both "onsite" and "offshore." }\end{array}$ \\
\hline$(6)$ & $\begin{array}{l}\text { Engagement } \\
\text { Manager }\end{array}$ & 3 years & Dec 20I2 & London & $\begin{array}{l}\text { Daily contacts with Eurobank client. } \\
\text { Has worked 3 years in the UK for InIT. }\end{array}$ \\
\hline$(7)$ & $\begin{array}{l}\text { Program director - head } \\
\text { of strategic initiatives }\end{array}$ & I7 years & Dec 20I2 & London & $\begin{array}{l}\text { Daily contacts with Eurobank client. } \\
\text { Has worked 7 years in the UK for InIT. }\end{array}$ \\
\hline$(8)$ & $\begin{array}{l}\text { Global account } \\
\text { executive }\end{array}$ & 8 years & Dec 20I2 & London & $\begin{array}{l}\text { Involved in several long-term relationships with major clients } \\
\text { in the banking and financial services industry. } \\
\text { Builds relationships with board level and IT/ operations } \\
\text { board executives in Eurobank on a daily basis. } \\
\text { Frequent contact with delivery heads in India. }\end{array}$ \\
\hline
\end{tabular}

I) To preserve anonymity, we sometimes refer to interviewees as 'top managers'

2) At the time of the first interview 
Table 3: Overview of the partners' various capitals

\begin{tabular}{|c|c|c|}
\hline Forms of Capital & Eurobank & InIT \\
\hline $\begin{array}{l}\text { Economic Capital } \\
\text { Command over economic resources }\end{array}$ & $\begin{array}{l}\text {-World-leading multinational financial } \\
\text { institution. } \\
\text {-High salary level at Western sites. } \\
\text {-Relatively small IT department due to } \\
\text { extensive outsourcing of maintenance and } \\
\text { development tasks. }\end{array}$ & $\begin{array}{l}\text { - Multinational top-tier IT service provider and part } \\
\text { of a large Indian conglomerate. } \\
\text {-Low salary level for offshore employees. } \\
\text {-Large pool of computer scientists and specialized } \\
\text { IT employees that makes it easy to scale up projects } \\
\text { quickly. }\end{array}$ \\
\hline Strength of the economic capital & Strong economic capital. & Strong economic capital. \\
\hline $\begin{array}{l}\text { Cultural Capital } \\
\text { Resources in the forms of knowledge (intellectual } \\
\text { capital), skills, academic credentials and } \\
\text { qualifications, mastery of languages, and access to } \\
\text { various cultural goods }\end{array}$ & $\begin{array}{l}\text {-A culturally diverse workforce in its } \\
\text { European headquarter and numerous } \\
\text { subsidiaries. } \\
\text {-Extensive domain specific knowledge } \\
\text { within financial services. } \\
\text {-English as "lingua franca" and some local } \\
\text { languages. Some IT managers have low } \\
\text { English proficiency. }\end{array}$ & $\begin{array}{l}\text {-Most employees educated at Indian universities, but } \\
\text { all constantly trained in various technologies and } \\
\text { computer languages and in virtual teamwork across } \\
\text { borders. } \\
\text {-Top and middle managers well-traveled and } \\
\text { experienced with international collaboration. } \\
\text {-Strong domain-specific knowledge (computer } \\
\text { science and software development). } \\
\text {-Recruits people at client locations with deep local } \\
\text { and global knowledge of financial services. } \\
\text {-Has developed a center of excellence with specific } \\
\text { products for the financial services industries. } \\
\text {-High proficiency in English as lingua franca. }\end{array}$ \\
\hline Strength of cultural capital & Strong cultural capital in finance. & Strong cultural capital in IT and English. \\
\hline Social Capital & -Participants in Indian offshore teams. & -"Onsite" participants in Europe, Singapore and \\
\hline
\end{tabular}




\begin{tabular}{|c|c|c|}
\hline $\begin{array}{l}\text { Resources based on membership of groups and } \\
\text { durable networks of influence and support }\end{array}$ & $\begin{array}{l}\text {-Easy access to business stakeholders and } \\
\text { senior vendor managers ('onsite' and } \\
\text { 'offshore'). }\end{array}$ & $\begin{array}{l}\text { Sydney. } \\
\text {-Easy access to business stakeholders and senior IT } \\
\text { client managers ("onsite" and "offshore"). } \\
\text {-Strong network of strategic and solution partners, } \\
\text { so-called "global alliances." }\end{array}$ \\
\hline Strength of social capital & Strong social capital. & Strong social capital. \\
\hline $\begin{array}{l}\text { Symbolic Capital } \\
\text { Resources available on the basis of prestige and } \\
\text { recognition }\end{array}$ & $\begin{array}{l}\text {-Client seen as a front-edge financial } \\
\text { provider. } \\
\text { - Client selects vendors for various } \\
\text { subprojects and decides on multiple vendor } \\
\text { set-ups. } \\
\text {-Client representatives have the authority to } \\
\text { review and assess outcomes of development } \\
\text { projects, and to put subprojects on hold. }\end{array}$ & $\begin{array}{l}\text { - On the list of global top-5 preferred vendors due } \\
\text { to InIT's vast experience with transformation } \\
\text { initiatives and its perceived high level of quality. } \\
\text {-Maturity level } 5 \text { CMMI-certificated for } \\
\text { development. } \\
\text {-No. I in customer satisfaction in Europe. }\end{array}$ \\
\hline Strength of symbolic capital & Strong symbolic capital. & Strong symbolic capital within the industry. \\
\hline
\end{tabular}


Table 4: Modes of relationships between client and vendor

\begin{tabular}{|c|c|c|c|}
\hline Modes of & \multicolumn{2}{|l|}{ Characteristics } & Illustrative quotes \\
\hline \multirow[t]{3}{*}{$\begin{array}{l}\text { Outsourcing } \\
\text { I.0 }\end{array}$} & Main activity & Staffing & $\begin{array}{l}\text { This is more of a staff augmentation mode where they will tell that you just give me your } \\
\text { people, and work with us.. (\#3) }\end{array}$ \\
\hline & $\begin{array}{l}\text { Type of } \\
\text { product/service }\end{array}$ & Standard & \multirow{2}{*}{$\begin{array}{l}\text { They will say give me } 10 \text { people who know Java, and you charge at the end of the month } \\
\text { at the rate of } x, y \text { or } z \text { and that's the end of it. (\#8) }\end{array}$} \\
\hline & $\begin{array}{l}\text { Type of } \\
\text { relationship }\end{array}$ & $\begin{array}{l}\text { Limited } \\
\text { contractual } \\
\text { relationship }\end{array}$ & \\
\hline \multirow[t]{3}{*}{$\begin{array}{l}\text { Outsourcing } \\
2.0\end{array}$} & Main activity & $\begin{array}{l}\text { Delivering a } \\
\text { command }\end{array}$ & \multirow{2}{*}{$\begin{array}{l}\text { Outsourcing } 2.0 \text { would mean [the client says:] I don't care whether you put I0 people or } \\
\text { I5 people, I want this outcome. I want this nice looking website working beautifully well } \\
\text { and doing all my transactions. (\#8) }\end{array}$} \\
\hline & $\begin{array}{l}\text { Type of } \\
\text { product/service }\end{array}$ & Standard & \\
\hline & $\begin{array}{l}\text { Type of } \\
\text { relationship }\end{array}$ & Client/vendor & So now your Java people become IT architects (...) That is outsourcing 2.0. (\#8) \\
\hline $\begin{array}{l}\text { Outsourcing } \\
3.0\end{array}$ & Main activity & $\begin{array}{l}\text { Developing a } \\
\text { product together, } \\
\text { involving several } \\
\text { actors into } \\
\text { product/service } \\
\text { development, } \\
\text { innovation }\end{array}$ & $\begin{array}{l}\text { [Early in the } 2000 \text { s] when nobody was talking about utilities with Eurobank, we worked } \\
\text { along with them in creating a utilities solution. We had the IT Department, the Bank } \\
\text { became the business partner, and we had the solution partner. All three of us sat together } \\
\text { and then created a utility model. That is possible only when you have a very strong } \\
\text { relationship. So I think those sort of levels }(. .) \text { we call it outsourcing 3.0. Things like } \\
\text { joint IP development, creating new utilities and areas or services that had never existed. } \\
\text { (...) } \\
\text { Innovation requires investments from both sides, commitment from both sides and } \\
\text { working together towards the solution. Then on top of it, finally, I think management } \\
\text { commitment from both sides, (...) at this level of discussion, the strategic level, we have }\end{array}$ \\
\hline
\end{tabular}




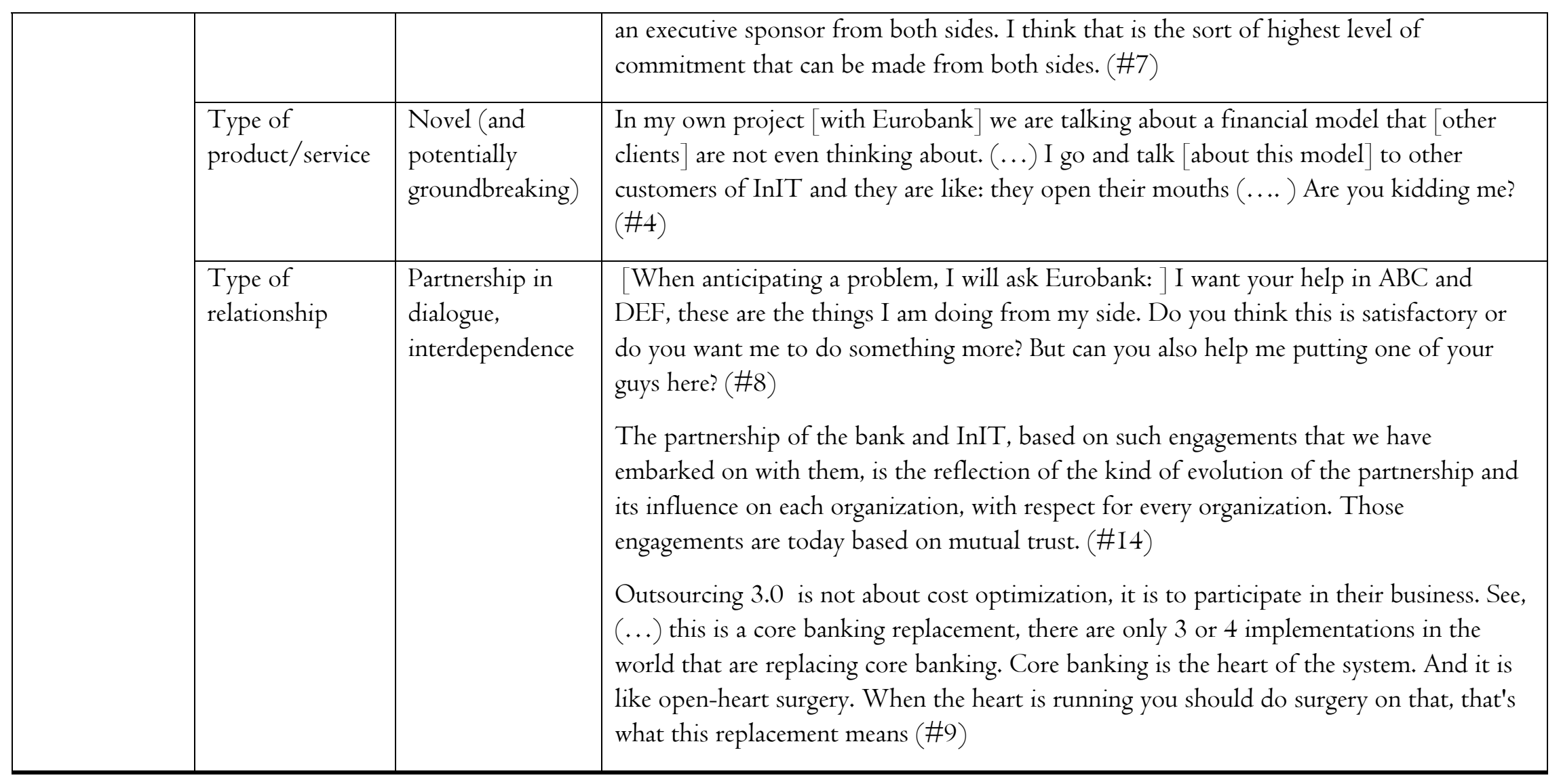


Table 5: Boundary-spanning activities

\begin{tabular}{|c|c|c|}
\hline Activity & Aim & Illustrative quotes \\
\hline \multicolumn{3}{|r|}{ Managing Boundaries } \\
\hline Buffering & $\begin{array}{l}\text { Monitoring and } \\
\text { protecting the flow of } \\
\text { information and } \\
\text { resources across groups } \\
\text { to define boundaries and } \\
\text { build intergroup safety }\end{array}$ & $\begin{array}{l}\text { Sometimes you have to put your foot down even with the customer. Because we have to protect at the } \\
\text { end of the day the interests of }[\operatorname{InIT}] \text {, and the reputation of }[\operatorname{InIT}](\ldots) \text { We tell them upfront we } \\
\text { can't do this. (...) At those times I take a more, you know, (...) a little aggressive stance }(\# 4) \\
\text { My offshore team will be more comfortable interacting with my IT designer [in London] }(\ldots) \text { I can't } \\
\text { call [Eurobank] every time, so because of the proximity this guy onshore [close to the client] he can } \\
\text { walk [my team], he can talk the guys whatever doubts [they may have]. (\#5) }\end{array}$ \\
\hline Reflecting & $\begin{array}{l}\text { Representing distinct } \\
\text { perspectives, encouraging } \\
\text { knowledge exchange } \\
\text { across groups to } \\
\text { understanding } \\
\text { boundaries and fostering } \\
\text { intergroup respect }\end{array}$ & $\begin{array}{l}\text { [Europeans] (...) might sound rigid, or a bit rude sometimes. But actually, they do not really mean it, } \\
\text { it is just the language they use, it is like they are converting [their native language] into English ... so } \\
\text { for an offshore guy, he feels that 'why is he so harsh on me'? So then I tell him 'he is not being harsh. } \\
\text { He is just using the language that he knows.' (\#7) } \\
\text { It's like if you talk to a person from Germany, that person will always think in terms of step I, step 2, } \\
\text { step 3, step 4, step 5. Whereas I'll go to step I, and then I may go to step } 3 \text { and may go back to step } \\
\text { 2. (...) It's a culture, it's a way that people think and people interact and that culture difference can be } \\
\text { [challenging], it's not easy to resolve that when you are interacting over phone or even video } \\
\text { conference. (\#I4) } \\
\text { The pace and the thought process [between Eurobank sites in London or Frankfurt], I find it } \\
\text { completely different. (...) You need to keep shifting, when you talk to people in London, we talk very } \\
\text { much the language that they would like to hear. Whereas when I go to Germany, then I think we really } \\
\text { start thinking a lot more slow and steady, I would call it, and much more long-term oriented, instead } \\
\text { of the immediate short term benefit. (\#7) }\end{array}$ \\
\hline \multicolumn{3}{|r|}{ Forging common ground } \\
\hline Connecting & $\begin{array}{l}\text { Linking people and } \\
\text { bridging divided groups } \\
\text { to suspend boundaries } \\
\text { and build intergroup } \\
\text { trust }\end{array}$ & $\begin{array}{l}\text { It is more of a confidence builder: they see the team, they personally meet everybody (...) So they have } \\
\text { good connections with everyone. (...) Currently there is one from the customer setting [stationed] all } \\
\text { the time [at the offshore site] (\#I) } \\
\text { Although you can collaborate on phones, it is always better to have a first personal contact. So usually } \\
\text { what happens is that when kicking off in any new country, we have two or three days workshop and }\end{array}$ \\
\hline
\end{tabular}




\begin{tabular}{|c|c|c|}
\hline & & $\begin{array}{l}\text { some of us go and participate in that so we [client and vendor representatives] know each other, and } \\
\text { then after that we continue from our offshore [sites] over teleconferencing (\#I0) } \\
\text { The face-to-face interactions which happen during the workshops in formal and informal settings (...) } \\
\text { allow new people from the team to come in, get introduced, interact, understand each other and (...) } \\
\text { subsequent interactions when they happen over such modes of [virtual] communication or over an e- } \\
\text { mail, even that gets respected. Trust built in the workshops really helped the program, and of course } \\
\text { the trust will continue and hopefully will evolve over the program. (\#I4) } \\
\text { Chat is the biggest medium [of communication] with the customer and it's a good way to see how } \\
\text { much time people are at their desk and what they are exactly doing. (\#6) }\end{array}$ \\
\hline Mobilizing & $\begin{array}{l}\text { Crafting common } \\
\text { purpose and shared } \\
\text { identity across groups to } \\
\text { reframe boundaries and } \\
\text { develop intergroup } \\
\text { community }\end{array}$ & $\begin{array}{l}\text { When a customer travels all the way to Bangalore and goes to the person and says 'Thank you for the } \\
\text { good job done,' that gives the individual a completely different experience. So he feels really important. } \\
\text { (\#7) } \\
\text { I personally was there ["onsite"] three - four weeks and was monitoring the situation. We put } \\
\text { additional people, we put more skills, like brought in the [external consulting] experts, made the team } \\
\text { get used to [them]. Our team has to learn as well as the Eurobank team (has to learn) because they also } \\
\text { can deflect some of the issues there themselves (...) So a lot of improvements and effort were made by } \\
\text { [Eurobank] and [InIT]. The customer was jointly working with us to see that it was stabilized. (\#2) } \\
\text { Typically when we get a new project then you know to get everybody involved [from Eurobank and } \\
\text { InIT], we come together daily and give them their requirements (...) And the benefit of these } \\
\text { workshops is that at the end of it you get a very unified view of what everyone thinks. (\#8) }\end{array}$ \\
\hline \multicolumn{3}{|r|}{ Discovering new frontiers } \\
\hline Weaving & $\begin{array}{l}\text { Drawing out and } \\
\text { integrating group } \\
\text { differences within a } \\
\text { larger whole to interlace } \\
\text { boundaries and advance } \\
\text { intergroup } \\
\text { interdependence }\end{array}$ & $\begin{array}{l}\text { Then I say: 'Boss, you have to understand our problem as well, and you need to abide by certain rules } \\
\text { of the game, as a joined team, as a partner. Forget about supplier or customer relationship, nowadays it } \\
\text { is more of a partner science. (...) It's a joint responsibility. It's not like you signed a contract with me } \\
\text { and I am supplying some goods to you. If you work in that model we will be in a bigger pain, in a } \\
\text { bigger problem, instead of working as a joined partner and trying to improve things together.' That } \\
\text { requires maturity and understanding from both sides, I would say. (\#6) } \\
\text { [You see it in] how they [Eurobank] disclose their internal plans, (...) they will tell you what they } \\
\text { want to achieve because now their goals are sort of my goals. (\#8) }\end{array}$ \\
\hline
\end{tabular}




\begin{tabular}{|c|c|c|}
\hline & & $\begin{array}{l}\text { Yes, mutual responsibility. Fixing maybe, per se, was [InIT] responsibility, but all through the process } \\
\text { [of resolving an issue] customer was there with us (\#2) } \\
\text { It is not a vendor-client kind of a relationship, it is a partnership where the success of EuroBank is } \\
\text { actually the success of InIT and vice versa. Basically, if a project fails both will take a hit. (\#5) } \\
\text { [This service] is being enriched based on (...) the knowledge of the people from the Eurobank as well } \\
\text { as based on the knowledge of the people that we [InIT] have deployed in this team. (\#I4) }\end{array}$ \\
\hline $\begin{array}{l}\text { Trans- } \\
\text { forming }\end{array}$ & $\begin{array}{l}\text { Bringing multiple groups } \\
\text { together in emergent } \\
\text { new directions to cross- } \\
\text { cut boundaries and } \\
\text { enable intergroup } \\
\text { reinvention }\end{array}$ & $\begin{array}{l}\text { We had the IT department, [Eurobank] became the business partner and we had the solution partner. } \\
\text { So all three of us sat together and then created a [ground-breaking] utility model. That is possible only } \\
\text { when you have a very strong relationship with an executive sponsor from both sides. I think that is the } \\
\text { sort of highest level of commitment that can be made from both sides. } \\
\text { (\#7) } \\
\text { [Eurobank] is quite advanced in some things, so for example in my own project we are talking about a } \\
\text { financial model which people are not even thinking about. (...) When [Eurobank] comes to [InIT] } \\
\text { for a large transformation program, they don't just expect us to deliver what they want. They want } \\
\text { something more. (...) If the customer is at the leading edge of technology, he is going to carry you } \\
\text { along with him because you are going to be delivering those IT services that you then learn here, and } \\
\text { you can go and use that knowledge to support other customers. (\#4) } \\
\text { Because when they [Eurobank] come to [InIT] for a large transformation program, they don't just } \\
\text { expect us to deliver what they want. They want something more. (...) We decided to create this } \\
\text { strategic initiative team to focus primarily on this large transformation program where we are able to } \\
\text { give some special attention and (...) a change in terms of the revenue we are looking for (\#7) } \\
\text { [Eurobank] has been able to survive because we [InIT] have been working in all of these areas such as } \\
\text { risk management and multivendor issues and all that [that benefited Eurobank]. So now we are trying } \\
\text { to give some sort of knowledge to other banks wherever possible. (\#5) }\end{array}$ \\
\hline
\end{tabular}


Table 6: Dimensions of transparency

\begin{tabular}{|c|c|}
\hline Transparency & Illustrative quotes \\
\hline $\begin{array}{l}\text { Structure: } \\
\text { How the project will be } \\
\text { structured, the role of the } \\
\text { various actors involved }\end{array}$ & $\begin{array}{l}\text { You essentially need to define the organizational structure whatever project program you are running. (...) Then you need to } \\
\text { define the governance. I mean how many meetings you are going to have? When will the customer be required to connect } \\
\text { directly with colleagues in India? In what roles? [The] customer needs to understand how you are deploying or structuring } \\
\text { your detailed team to deploy that piece of work. (\#4) }\end{array}$ \\
\hline $\begin{array}{l}\text { People: } \\
\text { Who is working on the } \\
\text { project, how many hours are } \\
\text { they working, etc. }\end{array}$ & $\begin{array}{l}\text { When you are selling skills, you need to maintain a transparency that you have provided the agreed skill resource. So [the } \\
\text { client] can see that these resources involve that skill and they are delivering the hourly value that the customer is paying. (...) } \\
\text { As part of your transparency, you are giving the customer a chance to talk directly to the people on the ground about who are } \\
\text { doing the work. So he feels more comfortable instead of me just talking and giving him nice presentations and nice pictures } \\
\text { and nice meetings. (\#6) } \\
\text { Customers used to say, I come to the office at 7:45 in the morning, I don't see any of your guys, and I say, yes, but X was } \\
\text { there till } 2 \text { o'clock in the morning. You were not there at the office. So we also have to educate the customer. (\#4) }\end{array}$ \\
\hline $\begin{array}{l}\text { Task: } \\
\text { Progress in the completion } \\
\text { of the task, access to the } \\
\text { work done }\end{array}$ & $\begin{array}{l}\text { [InIT] delivers projects for [Eurobank] by sitting in the [Eurobank] IT environment and working there so that they can } \\
\text { always see what we are doing. In that way, ground-level transparency is also there. So if I have written five lines of code, if I } \\
\text { have generated five files, one of the customer representatives has access, he can always go and check. (...) whether all the } \\
\text { suppliers are complying with security policies: that way, the collaboration works. (...) } \\
\text { [Chat] is a good mechanism to see how long people are there at their desks and what they are exactlydoing. (...) Chat is also } \\
\text { considered an official communication medium and is a transparency enabler, I would say. So I am sitting ["onsite"] and I } \\
\text { don't know what is happening in that room ["offshore"], but through all the chat and talking to the people I can imagine that } \\
\text { IO people must be sitting in that room, they are doing my work and I feel happy as a customer. (\#6) }\end{array}$ \\
\hline $\begin{array}{l}\text { Processes: } \\
\text { Whether there are issues } \\
\text { coming ahead, delays or } \\
\text { impediments }\end{array}$ & $\begin{array}{l}\text { So what we need to communicate to our teams globally is that if there is a problem, you should be the first person to tell your } \\
\text { customer. The transparency culture has to be there. (...) You know pretty much any partner, any vendor, will have that issue } \\
\text { at some point in time in the transaction with the customer. So you tell them beforehand and then tell them how you [will] } \\
\text { proactively manage it. (\#8) }\end{array}$ \\
\hline
\end{tabular}


Figure I: Case-related IT workplaces of Eurobank and InIT

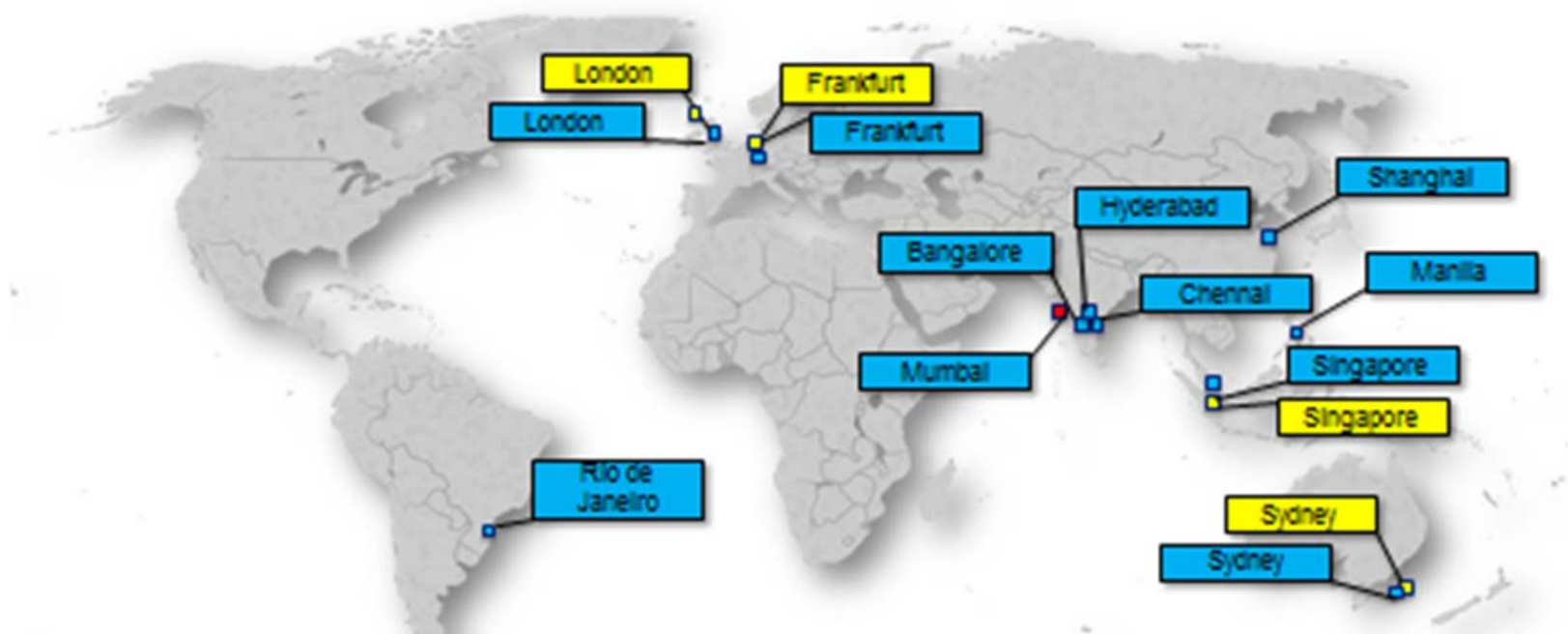

Eurobank $\square$

InIT $\square$ 